\title{
Kombucha microbiome as a probiotic: a view from the perspective of post-genomics and synthetic ecology
}

\author{
N. O. Kozyrovska, O. M. Reva ${ }^{1,2}$, V. B. Goginyan ${ }^{3}$, J.-P. de Vera ${ }^{4}$ \\ Institute of Molecular Biology and Genetics, NAS of Ukraine \\ 150, Akademika Zabolotnoho Str., Kyiv, Ukraine, 03680 \\ ${ }^{1}$ D. K. Zabolotny Institute of Microbiology and Virology, NAS of Ukraine \\ 154, Akademika Zabolotnoho Str., Kyiv, Ukraine, 03680 \\ ${ }^{2}$ Department of Biochemistry, Bioinformatics and Computational Biology Unit, University of Pretoria, South Africa \\ Lynnwood road, Hillcrest, Pretoria, South Africa, 0002 \\ ${ }^{3} \mathrm{SPC}$ «Armbiotechnology», NAS of Republic of Armenia \\ 14, Gyurjyan Str., Yerevan, Republic of Armenia, 0056 \\ ${ }^{4}$ Institute of Planetary Research, DLR, Germany \\ Rutherfordstr. 2D-12489, Berlin, Germany \\ kozyrna@ukr.net
}

\begin{abstract}
Probiotics are essential for establishing and maintaining optimal immune health. The probiotic therapy is known from alternative medicine for ages; however, the recent demonstration of the normal microflora to induce innate immunity has introduced the science-based concept of therapeutic application of potentially beneficial probiotic microorganisms for a treatment of functional disorders. Traditionally, probiotics are associated with dairy products, however, novel formulations are needed, first of all, originated from naturally occurring symbiotic microbial communities as the most robust assemblages. Especially, safe and robust probiotics are needed for longterm expeditions, outposts, extraterrestrial permanently-manned bases, where humans are exposed to adverse environmental factors. Kombucha beverage is Symbiotic Culture of Bacteria and Yeast (SCOBY) and associated with health-promoting effects. Kombucha tea/mat is being in use in human livings within millennia as a probiotic drink for healing and health prophylaxis effects, however, new research opportunities promise its «renaissance», going to be used pharmacologically.
\end{abstract}

Keywords: probiotics, kombucha microbiome, post-genomics, synthetic ecology.

Introduction. Products and probiotic preparations with beneficial microorganisms have formed the basis for functional human nutrition. The World Health Organization and the Food and Agriculture Organization of the United Nations have defined probiotics as «Live microorganisms which when administered in adequate amounts confer a health benefit on the host». Most often, the probiotic bacteria come from Lactobacillus or Bifidobacterium or cocktails (for example, Dr. Ohhira's Probiotics), however, soil and other bacteria in dairy, vegetarian or other formulas are accepted as

(ㄷ) Institute of Molecular Biology and Genetics, NAS of Ukraine, 2012 probiotics. A few common probiotics are yeasts such as Saccharomyces boulardii, S. cerevisiae etc. Important$1 \mathrm{y}$, administration of probiotics is effective, if nondigestible foods (cellulose fibers) are available in the diet. It is why prebiotics (food ingredients that selectively stimulate the growth and/or activity of beneficial microorganisms already in people's colons) are highly recommended, and along with probiotics these supplements known as synbiotics (a combination of prebiotics and probiotics). Examples of foods containing probiotics are yogurt, fermented and unfermented milk, miso, tempeh, some juices, fermented cabbage juice, and brews like kombucha tea. 
Probiotic microorganisms provide a balance in intestinal microbiota, normalizing processes in gut and boosting immune system [1]. The U. S. National Institute of Health has initiated Human Microbiome Project (HMP) to characterize the human microbiota [2]. The HMP has increased understanding of the diversity and genetics of the microbiota associated with the human body, and the next step of the project is microbial product characterization in a context of understanding the microbiome (including probiotic bacteria) functions and its relationship to health and diseases. In spite of tremendous progress in a study of beneficial human intestinal microorganisms with probiotic traits and its interrelationships with the host, the range of candidates for probiotics is mainly restricted to lactic acid bacteria and bifidobacteria. However, novel types of probiotics, especially, exhibiting diverse composition of naturallyoccurring symbiosis of beneficial microorganisms, could be promising and complementary for traditional probiotic foods and preparations.

Medusomyces gisevii Lindau represents a symbiotic microbial community known as tea «fungus» or kombucha tea (KT). The KT microorganisms co-exist in interdependent symbiotic relationships: during fermentation in sweet tea the added sugar is converted into organic acids and ethanol by yeast, and bacteria use the latter to produce cellulose fiber, forming a jellyfish-like zoogleal mat where microbial cells are attached. Finally, SCOBY gives a pleasant sweetish sour sparkling beverage under aerobic conditions. Organic acids and ethanol protect SCOBY from the colonization of other microorganisms, and this is a reason that keeps the SCOBY within ages. The representatives of yeast found in the SCOBY can vary and may include Brettanomyces/Dekkera, Schizosaccharomyces, Torulaspora, Zygosaccharomyces, Pichia [3-5]. Few bacterial species, originated from kombucha, Gluconacetobacter xylinus, G. kombuchae sp. nov., Acetobacter nitrogenifigens sp. nov, Acetobacter intermedius sp. nov. were isolated from different ecotypes of KT [6-8]. The exact microbiological composition depends on the source of the SCOBY, however, kombucha symbiotic culture must surely contain the acetic acid bacteria and yeast.

Kombucha-derived microorganisms produce a cocktail of diverse metabolites, and it is rich in fiber, organic and amino acids, especially, in lysine [9], vitamins [10,
11], antioxidants [12, 13], enzymes [14], essential elements ( $\mathrm{Na}, \mathrm{K}, \mathrm{Ca}, \mathrm{Cu}, \mathrm{Fe}, \mathrm{Mn}, \mathrm{Ni}$, and $\mathrm{Zn}$ ) [9]. Potential health effects of the SCOBY's metabolites have created an increased interest in kombucha drinks. The kombucha's greatest health benefits are its ability to detox and energize the body, improve digestion, boost immune system. KT is known from ages, however, scientific interest to SCOBY was increased at the beginning of the last century. Due to efforts of many scientific teams, positive effects of kombucha on immunological, endocrinological, cardiovascular, gastro-intestinal, urogenital and other levels were substantiated (see [12]). Approaching mid century, kombucha was established in official pharmacopoeia in Germany. However, in 60-s interest to kombucha declined probably on the reason of the wide expansion of synthetic pharmaceuticals. At the beginning of this millennium we observed kombucha's «renaissance» as the consequence of a slow returning to natural healing products, as well as research activity on the background of functional nutrition study. Recent well-documented research works on the KT administration have exhibited antimicrobial and antiproliferative activity $[13,15]$; improvement after lipid peroxidation and oxidative stress [16] and cytotoxicity [17] induced by environmental pollutants; antiobesity, hypocholesterolaemic and antioxidant effects [18]; ulcer-healing activity [19]; protective effect on chromosomal aberrations induced by gamma radiation [20]; the hepatoprotective effect against oxidative stress via suppression of mitochondria-dependent apoptosis [21].

Kombucha products raised interest in veterinary medicine. The supplementation of dried mat in animals and poultry feed had the positive influence on the treatment of intestinal infections, disbacteriosis, contaminated wounds, etc. [13, 22, 23] and thus increased performance observed in meat/egg characteristics. In parallel, we note that the kombucha mat and kombucha's secondary metabolites have applications in several other aspects. Bacterial cellulose (BC) synthesized by G. xylinus, an active component of the kombucha microbial community (KMC), is chemically pure, free of lignin and hemicellulose and may have several practical applications in nanobiotechnology and biomedicine [24, 25]. Diverse microbial metabolites like enzymes, organic acids and other biologicals originated from kombucha are in use, however, still manufactured by tradi- 
tional microbiological industry, despite the fact that biotechnology is declared as the leading science and technology in 21 century.

In this paper, we discuss the potential of kombucha microorganisms as probiotics from the position of current knowledge on the role of intestinal microbiota in immune system and perspectives of KMC from the point of post-genomics and synthetic ecology.

Intestinal indigenous microflora: effect on the immune system. Indigenous microbial communities serve important functions for the human host that are not prescribed in the human genome. Using metagenome data, Gill et al. [26] demonstrated that gut microbiota played beneficial roles in the human host by regulating many genes related to the metabolism of glycans, amino acids, biosynthesis of vitamins and isoprenoids and showed for the first time physiological phenomenon not regulated by human. Human gut microbiota also plays important roles in harvesting energy from the diet, stimulating the proliferation of the intestinal epithelium, regulating fat storage in the host [27]. However, the most intriguing role of human microbial associates is hidden in the developing of immune system.

Human commensals and mutualists. All surfaces of the human body, including the skin, mucosal surface and genital and gastrointestinal tracts are occupied by habitat-specific microorganisms (bacteria, archaea and fungi). The human intestinal microbiota is composed of $10^{13}$ to $10^{14}$ microorganisms whose cells outnumber those of the human body by ten times [26]. A new insight on human-microbial ecosystem as «a superorganism» provided by HMP. Its results showed that a number of total genes carried by associated microorganisms are two orders of magnitude higher than that contained in the human genome [18]. The human harbors a complex microflora, consisting of facultative and strict anaerobes, which includes more than 5000 species of bacteria [28]. Several reports indicated that in the colon microbial communities were dominated by five identified phyla: Actinobacteria, Firmicutes, Bacteroidetes, Fusobacteria, and Proteobacteria $[18,29]$. The vast number of bacteria in host tissues raises the question of how symbiotic host-bacterial relationships are maintained without eliciting potentially harmful immune responses.

Innate immunity and adaptive immunity. Infection of the human body by pathogenic microorganisms, viru- ses or parasites trigger the two-step immune response: innate immunity halts the infection and adaptive immunity subsequently clears, providing also systemic fast response on repetitive infection. The innate immunity can destroy invading microorganisms, triggering inflammation, however, does not confer long-lasting protection to the host. The innate immune system is an evolutionarily older defense strategy, and is the dominant immune system found also in plants, fungi, insects, and in primitive multicellular organisms. If the first step of defense is not effective, adaptive immunity is called into action. With its highly specialized systemic T, B, DCs (dendric cells) and other cells, it produces antibodies and killer cells that destroy infected cells. The adaptive immune system maintains an immunologic memory. The mechanisms, triggering the activation of innate immunity and mediating the communication between innate and adaptive immunity, have been cleared in series of research works [30-32] awarded by the Nobel Prize in 2011.

Innate immune responses to microorganisms, both pathogenic and beneficial, are triggered when the host recognizes specific structures, called pathogen-associated molecular patterns (PAMPs) or endogenous stress signals, called DAMPs (danger-associated molecular patterns) (BOX 1) [33].

BOX 1. PAMPs may include lipopolysaccharides, bacterial peptides, peptidoglycans, microbial nucleic acids, lipoteichoic acids etc. DAMPs include uric acid. PAMPs are recognized by pattern-recognition receptors (PRRs), such as membrane-bound Toll-like (TLRs) and cytoplasmic NOD-like (NLR) receptors, RIG-I-like helicases etc. [34-37]. Signaling PRRs include the large families of leucine-rich repeats (LRRs) in TLRs and NLRs, composed of a nucleotide-binding domain (NBD). In plants and animals, the most diverse family of PRRs is the cytoplamic NBD-LRR family, having more members than the cell surface LRR receptors, suggesting that NBD-LRRs can detect a large array of microorganisms, assembling inflammasomes with bacterial elicitors [38]. Endocytic PRRs promote the attachment, engulfment and destruction of microorganisms by phagocytes, without relaying on an intracellular signal. TLRs are localized on the surface of 
different $\mathrm{T}$ cells ( $\mathrm{T}$ lymphocytes) and epithelial cells, lining the intestinal tract [36]. Thelper cells (Th cells) provide signals for orchestrating the immune response. Once activated, Th cells divide rapidly and secrete cytokines (like interferon gamma, IFN $\gamma$, and tumor necrosis factor alpha, TNF $\alpha$ ) that regulate or assist in the active immune response. T helper type 1 (Th1) cells produce cytokine IFN $\gamma$ and control intracellular microorganisms (viruses and bacteria); the Th2 cells produce interleukins and control infections caused with extracellular microbes and helminths; the proflammatory Th17 cells have significant roles in protecting the host from bacterial and fungal infections [39]. Regulatory Tcells (Treg cells) are crucial for the maintenance of immunological tolerance (the process by which the immune system does not attack an antigen) [40]. After sensing microbial elicitors, PRRs activate various transcription factors, including universal Nuclear Factor-kappaB (NF- $\mathrm{kB})$ and interferon regulatory factors, to induce the production of proinflammatory cytokines and co-stimulatory molecules via MAP kinases cascades in intestinal epithelial cells and mucosal immune cells.

Either exo- or endogenous stress signals are being recognized with PAMP/DAMP immunity and further transduced via complex signaling cascades to the target genes encoding effector molecules that involved in tissue protection.

Universal NF- $\mathrm{kB}$ is a key element of the signaling cascades that ultimately regulates the transcription of defensive genes. Being in an inactivated state, NF- $\kappa B$ is located in the cytosol complexed with the inhibitory protein I $\mathrm{KB} \alpha$ [41]. Through the intermediacy of integral membrane receptors, a variety of extracellular signals can activate the enzyme IKB kinase (IKK). IKK, in turn, phosphorylates the $\mathrm{I} \kappa \mathrm{B} \alpha$ protein which results in ubiquitination, dissociation of $\mathrm{I} \kappa \mathrm{B} \alpha$ from NF- $\mathrm{kB}$, and degradation of $\mathrm{I} \kappa \mathrm{B} \alpha$ by the proteosome. The activated $\mathrm{NF}-\mathrm{kB}$ translocates into the nucleus where it binds to specific sequences of DNA called response elements. The DNA/NF- $\mathrm{KB}$ complex then recruits other proteins such as co-activators and RNA-polymerase which transcribe downstream DNA into mRNA [42]. Importantly, different pathogens elicit specific transcription programmes. A balanced indigenous microbiota is required to prevent or stop these programmes.

A role of intestine microbiota in the developing of immune system. Normal gut bacteria limit excessive inflammation through the suppression of $\mathrm{NF}-\mathrm{kB}$ signaling. Commensal microbiota regulate NF- $\mathrm{kB}$ activity in intestinal epithelial cells and mucosal immune cells [43, 44]. In normal homeostasis, indigenous bacteria specifically prevent NF- $\kappa \mathrm{B}$ activation by blocking ubiquitination of its inhibitor I $\mathrm{I} B \alpha$ that elicits an intracellular state of tolerance against further TLR activation $[45,46]$. The microbial factors positively or negatively regulate this key pathway: commensal bacterial DNA [47] or bacterially produced metabolites, such as ATP [48] or shortchain fatty acids (SCFA) (acetate, butyrate, propionate) [49] can exert profound effects on NF- $\mathrm{kB}$ activation.

Commensal bacteria educate $\mathrm{T}$ cells to be tolerant of foreign antigens. The education of $\mathrm{T}$ cells takes place in the thymus where self-reactive cells are either eliminated or differentiated in Treg cells [50]. Interestingly, colonic Treg cells used $\mathrm{T}$ cell antigen receptors different from those used by Treg cells in other locations, implying an important role for local antigens in shaping the colonic Treg cell population. It was shown that indigenous clostridia species induced Treg cells in the colonic lamina propria (a thin layer of the mucosa which lies beneath the epithelium) [51]. Segmented filamentous bacteria promoted the development of Th17 population in the small-intestinal lamina propria [52]. Relatedly, colonization of the mouse gastrointestinal tract with the human gut commensal Bacteroides fragilis or administration of one of its products, polysaccharide A, may have a substantial impact on both effector and regulatory $\mathrm{T}$ cell subsets, depending on the context [53]. These and other findings clearly demonstrate the role of normal gut microbiota in immunity status and dependence the status on its balance in the microbiome.

Human microbial communities are affected by external and internal factors that may disbalance its relationships with immune system. Comparative study of microbial community structure showed that these are lifestyle, dietary patterns, antibiotic usage, host genotype $[29,54-56]$ and so on. As a result, the structure of normal gut microbiome may change dramatically, and abnormal gut microflora may contribute to alterations in the mucosa and immune system, leading to diseases. The 
overgrowth of some intestinal opportunistic or pathogenic bacterial species as Clostridium difficile, Proteus spp., B. fragilis etc. results in functional disorders [57]. The change of human gut bacterial community is associated with obesity [58], type 1 diabetes (T1D) [59], hypertension [60], IBD, gastric and colonic cancers [61], multiple sclerosis (MS) (a devastating autoimmune disease leading to progressive deterioration of neurological function) [62]. Probiotics have the capacity to reverse deleterious changes in gut microbiota and local immunity.

Probiotics: immunomodulation of local and systemic response. The demonstration that gut microflora induces innate immunity has nourished a background for research on probiotics. Recent data show that probiotic microorganisms exert their protective effects by multiple immune and nonimmune mechanisms.

Probiotics have been shown to influence both innate and adaptive immunity or modify the composition and activity of the gut microbiota. One of the principal mechanisms of protection against gastroenteric infections by probiotics is via modulation of proinflammatory cytokines. Several strains of live lactic acid bacteria have been shown to induce in vitro the release of $\mathrm{TNF} \alpha$, interleukins, reflecting stimulation of innate immunity [63, 64]. Also the continuous lactobacilli administration, before and after Salmonella challenge, protected the mice hosts by modulating the inflammatory response, mainly in the immune effector site of the gut, decreasing TNF $\alpha$ and increasing IFN $\alpha$ and interleukins production in the small intestine [65]. Lactobacilli up-regulated human beta defensin-2 via induction of proinflammatory pathways, including NF- $\mathrm{KB}$ and AP-1, as well as MAPKs in human [66]. Oral introduction of Lactobacilli enhanced phagocytosis which responsible for early activation of the inflammatory response before antibody production $[67,68]$. Phagocytes release toxic agents, reactive oxygen intermediates and lytic enzymes in various inflammatory reactions. Phagocytic activity results in the further recruitment of immunocompetent cells and the generation of inflammatory response.

It is therefore interesting to note that probiotic bacteria were shown to modulate phagocytosis differently in healthy and allergic subjects: in healthy persons, there was an immunostimulatory effect, whereas in allergic persons, down-regulation of the inflammatory response was detected [69].

These examples show that Lactobacilli administration maintained the innate immune system in alert state through modulated expression of TLRs and cytokine signals in the effector and inductor site of the gut immune system and implicate the potential use of probiotic bacteria as immunomodulatory agents for humans. Specific probiotic bacteria possess significant anti-inflammatory properties which benefit in IBD, including Crohn's disease and ulcerative colitis [70]. Use of Lactobacillus species to combat human urinary tract infection is now giving modern concept of genitourinary vaccine that activates TLR and prevents inflammatory reactions in the response of pathogens [71].

Probiotics modulate the composition of the intestinal microflora, producing anti-microbial peptides such as defensins [72] and bacteriocins [73] against food-borne pathogens. Probiotic Bifidobacterium species have been shown to produce acetate which results in lowering $\mathrm{pH}$ in microeconiche, inhibition of human gut pathogens, and in the activation of immune response [74]. Indigested probiotic bacteria also modulate the metabolic activity of gut microbiota. In germ-free mice, whole genome transcriptional profiling showed that the exogenously administered probiotic Bifidobacterium longum expanded the variety of polysaccharides targeted for degradation by Bacteroides thetaiotaomicron which is a prominent member of the adult human gut microbiota [75].

Recent findings highlight the important role of commensal and mutualistic bacteria in the bidirectional communication of the gut-brain axis and suggest that certain microorganisms may prove to be useful therapeutic adjuncts in stress-related disorders such as anxiety and depression [76]. $\gamma$-Aminobutyric acid (GABA) is the main central nervous system (CNS) inhibitory neurotransmitter and is significantly involved in regulating many physiological and psychological processes. Alterations in central GABA receptor expression are implicated in the pathogenesis of anxiety and depression which are highly comorbid with functional bowel disorders. Chronic treatment with Lactobacillus rhamnosus can alter the transcript level for receptors of the neurotransmitter GABA in the CNS in a region-dependent manner. Recent and future advances in functional 
genomics and transcriptomics allow elaborate the personal probiotics-based TLR-therapy which comes true even in local clinics in the future.

Symbiotic kombucha microbial community as a synbiotic. A work in extreme conditions (mines, submarines, polar expeditions, space stations etc.) needs the robust immune system and balanced indigenous intestinal microbiota. The reason is that the microbiome of crews may deviate substantially from that of its normality as a result of unusual external influences, as well as psycho-emotional discomfort in hostile conditions. Combined with sharp changes in diet and the increasing sanitary conditions in which crews live, their state of gut colonization by normal microbiota may be dysbiotic. Protective gut commensals and mutualists may disappear, leading to secondary infection by opportunistic microbes, and may have large health consequences such as altering predisposition to allergies and autoimmune disease, T1D, MS. Reverse altering community composition in a positive way may not be quite as straightforward, however, correction with probiotics and prebiotics may be reasonable. The microbiome-focused therapeutics is focused on altering the composition of the community and endowing it with new functions.

Currently probiotics reached a new frontier and may contribute to the maintenance of human health under unearthly circumstances. The National Aeronautics and Space Administration (U. S.) is starting to look at how to use probiotics in foods for astronauts. For this purpose $L$. rhamnosus as leading probiotic bacterium is a promising species. The astronaut's diet is not rich enough in vegetables (soluble and insoluble fibers), and taking probiotics may not be so effective, because of insufficient food sources for the probiotic bacteria do not support them in the intestines. Kombucha tea/mat may be a promising formulation of a probiotic/prebiotic for extreme expeditions on several reasons [77]:

- kombucha provides a source of both probiotic bacteria and yeast, as well as prebiotics (microcellulose) which help fuel the growth of helpful microorganisms in digestive track; KMC may be accepted as a synbiotic;

- kombucha provides SCFAs and other metabolites which boost immunity;

- the diversity of naturally occurring symbiotic microorganisms and appropriate wide range of their activity are advantageous in KT over single strain-probio- tics or artificially assembled communities of beneficial microbial strains;

- due to kombucha biofilm, the starter is practically immortal and can be activated when needed. This means that the longevity of the KT shelf-life has no sense;

- slow-growing biofilms produce substantial numbers of persisters (a subpopulation of dormant cells which tolerate adverse factors);

- multiple healing effects; an energizer;

- KMC has metabolic plasticity and can be adapted to various feeding resources;

$-\mathrm{KMC}$ is resistant to adverse abiotic factors as a high dose of UV radiation, vacuum etc. in model experiments (will be published);

- kombucha is easily, safely and at low cost and labor produced in situ (at home, expeditions, out-posts etc.);

- the final KT product, a slightly carbonated, acidicsweetish beverage, resembling cider or champagne, is to create delight and positive emotions.

In spite of tremendous interest to the health-promoting activity of $\mathrm{KMC}$, there is no systemic scientific approach to characterizing KMC collective genome and its expression in changed environment, using new research opportunities (BOX 2). Practically all findings in a study of kombucha microbial symbiosis have been done with traditional microbiological approach.

BOX 2. Post-genomics as a new field of research has been developed over the past decade for comprehensive study of individual and community organisms and includes metagenomics, transriptomics, proteomics, metabolomics and other «omics». Metagenomics is the cultivation-independent analysis of the collective genomes of microbial communities within a given environment, using sequence- and function-based approaches [78]. Metagenomics is developed to elucidate the community genomes with the goal to better understand global microbial ecology. On the other side, metagenomics has been driven by the increasing biotechnological demands for novel enzymes and biomolecules. Since it is well accepted that the majority of microbes has not yet been cultured, these microorganisms represent intriguing hidden new knowledge, as well as a resource 
for the development of novel genes, enzymes and chemical compounds for use in biotechnology, pharmaceutical industry etc. Transcriptomics is the study of the transcriptome, the complete set of RNA transcripts, produced by the genome at any one time. The transcriptome shows the activity of genes at the given moment. Metabolomics is the scientific study of chemical processes involving metabolites. The pool of small-molecule metabolites present in a biological cell, tissue, organ or organism as the end-products of cellular processes under specific physiological state is metabolome. Metabolomics relies on the entire set of genes in an organism $/ \mathrm{s}$ genome/metagenome - to study physiology.

Metagenomic approach in a study of microbial ecosystems allows reconstructing the community structure and transcriptome on the base of a high-throughput DNA sequencing and analysis of annotated sequences with bioinformatics programs. The use of such an approach for a study of the KMC structure will unmask not-yet-cultivated microorganisms which are expected in such biofilms as SCOBY and stop discussions about hidden deleterious microbes. Metagenomics approach may help by allowing comprehensive documentation of changes in the gut «microbiome» of a given individual as a function of probiotic administration, including comsumption of KT. It is important for the evaluation of dietary products, consuming as probiotics. Recent advances in the HMP have furthered our understanding of probiotic functionality and the specific interactions between probiotics and their human hosts (see rev. [79]). The ability to examine fully sequenced and annotated kombucha genomes will promote the application of genetic approaches to elucidate many important functional roles of probiotic kombucha microbes. A parallel study of effects of KMC on indigenous or transient human microbiota, as well as on the immune system markers allows elaborating the personal kombu chabased corrections of functional disorders in a patient-friendly manner.

How do we make sure that probiotic bacteria do not lose positive and do not endow negative features under effect of adverse conditions? In other words, what respond will be to environmental factors, influencing probiotics functional properties? These questions are ad- dressed to functional genomics and transcriptomics. Knowledge about the KMC transcriptomes at standard and changed conditions (which may provoke to develop populations of persisters and other latent microbes) will invest in the evaluation of putative hidden effects on human health, as well as in the study of bacteriayeast interrelationships.

The kombucha culture is a tiny biochemical factory, producing valuable health-promoting substances. Up to date, there is inconsistency in the results of chemical analysis of the kombucha metabolome, and we see a solving this problem in a comprehensive study of kombucha metabolome with modern analytical technique and programs in order to identify and characterize bioactive compounds and to study their role in healing diseases and modulation of immune system. The annotated KMC metagenome and deciphered KMC metabolic pathways and their networks will create a basement for separation and a study of unknown valuable specific compounds needed for the design of recombinant technology and high-throughput producing. This will be helpful for metabolic engineering approach and construction of more efficient pathways of sugars utilization from waste plant materials by KMC during KT fermentation. Basic science efforts, especially synthetic biology and systems biology (BOX 3), lead to the way that will enable genetic engineering of KMC to endow its members with new desirable functions that treat disease or promote health.

BOX 3. Synthetic biology aims a better understanding of biological systems through constructing them. Synthetic biology is a methodology for analyzing the dynamics of small biological networks to predict their behavior in experimental and computer models and the transition to more complex networks in order to understand the functioning of the model in the given conditions. In the broadest sense of the term, synthetic biology used to describe integrated approaches to solving problems of biology and a holistic view of life. Systems biology is interdisciplinary study field that focuses on complex interactions in natural biological systems. Synthetic ecology is the science of human-altered and humancreated ecosystems. In this sense «synthetic» means either artificial fabrication or arrangement of synthe- 
sis. Synthetic ecology either mimics an analog of a particular environment which exists in nature, or invents a synthetic one based on natural or genetically modified environment. Synthetic ecology will undoubtedly be a lively area of research in the coming years, especially, in elaborating autonomous lifesupport systems, and will benefit from the tools and strategies of synthetic biology. Ecological engineering is a study of integrating ecology and engineering, anticipating the design, monitoring and construction of ecosystems, including microecosystems.

In coming future, the engineering of the kombucha microbiota to interact directly with the human host in new ways (catabolism of cholesterol, production of valuable biologicals in gut, etc.) on the basement of deciphered individual gut microbiome will be possible. Novel cooperative robust synthetic ecosystems composed of yeast and bacteria strains, like CoSMO (for Cooperation that is Synthetic and Mutually Obligatory) [80], will be constructed for healing purposes. Synthetic approaches can then be combined with analysis in the laboratory and in nature to triangulate the rules of natural systems.

Both natural and genetically engineered kombucha microbiome will be the indispensable component of regenerative life-support system. In addition to a probiotic for crew, KT is a promising probiotic for growing plants, and a kombucha mat could be used for both crews and animals feeding as a rich source of biologicals. The kombucha jelly-like mat is a valuable resource for a formation of fertile soil.

Returning from the far future to nowadays, we may conclude that post-genomics tools will make a progress in the research of SCOBY, and the output of post-genomics studies will raise, first of all, a vote of confidence to natural healing kombucha products. Secondly, studies on functional metagenomics would provide evidences on healing effects of KT and kombucha mat and create a basement for safe use of these products in adverse conditions of long-term earthly expeditions and in the future space missions or extraterrestrial bases. Kombucha is known over two thousand years and still has the potential to serve humans for health promotion, especially, in autonomous life-support systems.
Н. О. Козировська, О. М. Рева, В. Б. Гогінян, Ж.-П. Девера

Мікробіом чайного гриба як пробіотик: погляд з позиції постгеноміки і синтетичної екології

Резюме

Пробіотики мають істотне значення для встановлення $i$ підтримки оптимального імунного здоров'я. Пробіотична терапія здавна відома з народної медицини, проте демонстрачія того, що мікрофлора кишечника індукує вроджений імунітет, представила науково обгрунтовану конщепиію терапевтичного застосування потенційно корисних мікроорганізмів. Традиційно пробіотики пов'язані з молочними продуктами, тим немени, для зміцнення здоров'я $\epsilon$ потреба у нових препаратах, основу яких складають, пери за все, природні симбіотичні мікробні угруповання. Особливо безпечні і надійні пробіотики необхідні для тривалих експедицій, у тому числі позаземних, іншопланетних баз, де люди піддаються дії несприятливих чинників довкілля. Через ие профілактика та коригування імунної системи за допомогою пробіотиків стають особливо важливими. Комбуча (чайний гриб) $\epsilon$ симбіотичним угрупованням бактерій та дріжджів і відомий як напій, що зміџнює здоров'я. Сучасні методи дослідження перебувають на стадї відновлення популярності комбучі як пробіотика для лікування і профілактики багатьох захворювань. Препарати комбучі у недалекому майбутньому використовуватимуться як фармакологічні.

Ключові слова: пробіотики, постгеноміка, синтетична екологія.

\section{Н. А. Козыровская, О. Н. Рева, В. Б. Гогинян, Ж.-П. Девера}

Микробиом чайного гриба как пробиотик: взгляд с позиции постгеномики и синтетической экологии

Резюме

Пробиотики имеют существенное значение для установления и поддержания оптимального иммунного здоровья. Пробиотическая терапия издавна известна из народной медицины, однако демонстрачия того, что микрофлора кишечника индуцирует врожденный иммунитет, предоставила научно обоснованную конщепиию терапевтического применения потенциально полезных микроорганизмов. Традиционно пробиотики связаны с молочными продуктами, тем не менее, для укрепления здоровья возникает потребность в новых препаратах, основу которых составляют, в первую очередь, природные симбиотические микробные сообщества. Особенно безопасные и надежные пробиотики необходимы для длительных экспедииий, в том числе внеземных, инопланетных баз, где люди подвергаются действию неблагоприятных факторов окружающей среды. В связи с этим профилактика и коррекиия иммунной системы с помощью пробиотиков особенно важны. Комбуча (чайный гриб) - это симбиотическое сообщество бактерий и дрожжей, известный как напиток, укрепляющий здоровье. Современные методы исследования находятся на стадии восстановления популярности комбучи как пробиотика для лечения и профилактики многих заболеваний. Препараты комбучи в недалеком будущем будут использовать как фармакологические.

Ключевые слова: пробиотики, постгеномика, синтетическая экология.

\section{REFERENCES}

1. Fukushima Y., Hurt E. Probiotics health claims in Japan and Europe // Lactic acid bacteria and bifidobacteria: Current progress 
in advanced research / Eds K. Sonomoto, A. Yokota.-Hokkaido: Caister Acad. Press, 2011.-286 p.

2. Turnbaugh P. J., Ley R. E., Hamady M., Fraser-Liggett C. M., Knight R., Gordon J. I. The human microbiome project // Nature.-2007.-449, N 7164.-P. 804-810.

3. Danielian L. T. To chemical content and physiological and morphological properties of Kombucha's cultural liquid // Transactions of YSZVI.-1957.-22.-P. 111-121.

4. Mayser P., Fromme S., Leitzmann C., Grunder K. The yeast spectrum of the «tea fungus Kombucha» // Mycoses.-1995.-38, N 78.-P. 289-295.

5. Teoh A. L., Heard G., Cox J. Yeast ecology of Kombucha fermentation // Int. J. Food Microbiol.-2004.-95, N 2.-P. 119-126.

6. Kurtzman C. P., Robnett C. J., Basehoar-Powers E. Zygosaccharomyces kombuchaensis, a new ascosporogenous yeast from «Kombucha tea» // FEMS Yeast Res.-2001.-1, N 2.P. $133-138$

7. Dutta D., Gachhui R. Nitrogen-fixing and cellulose-producing Gluconacetobacter kombuchae sp. nov., isolated from Kombucha tea // Int. J. Syst. Evol. Microbiol.-2007.-57, pt 2.-P. 353-357.

8. Dutta D., Gachhui R. Novel nitrogen-fixing Acetobacter nitrogenifigens sp. nov., isolated from Kombucha tea // Int. J. Syst. Evol. Microbiol.-2006.-56, pt 8.-P. 1899-1903.

9. Jayabalan R., Malini K., Sathishkumar M., Swaminathan K., Yun S.-E. Biochemical characteristics of tea fungus produced during kombucha fermentation // Food Sci. Biotechnol.-2010.-19, N 3.-P. 843-847.

10. Bauer-Petrovska B., Petrushevska-Tozi L. Mineral and water soluble vitamin content in the Kombucha drink // Int. J. Food Sci. Technol.-2000.-35, N 2.-P. 201-205.

11. Velicanski A. S., Cvetkovic D. D., Markov S. L., Tumbas V. T., Savatovic $S$. M. Antimicrobial and antioxidant activity of lemon balm Kombucha // Acta periodica technologica.-2007.-38.P. $165-172$.

12. Danielian L.T. Tea fungus.-Yerevan: Publ. house «Armenia», 1993. $-112 \mathrm{p}$

13. Goginyan V. B. Antioxidant properties of Tea fungus (Kombucha) and its microflora // Biol. J. Armenia.-2001.-53.-P. 296299.

14. Danielian L. T. Kombucha - biological features.-Yerevan: Publ. house «Asogik», 2002.-256 p.

15. Cetojevic-Simin D. D., Bogdanovic G. M., Cvetkovic D. D., Velicanski A. S. Antiproliferative and antimicrobial activity of traditional Kombucha and Satureja montana L. Kombucha // J. BUON.-2008.-13, N 3.-P. 395-401.

16. Gharib O. A. Effects of Kombucha on oxidative stress induced nephrotoxicity in rats // Chin. Med.-2009.-4.-P. 23.

17. Yapar K., Cavusoglu K., Oruc E., Yalcin E. Protective effect of kombucha mushroom (KM) tea on phenol-induced cytotoxicity in albino mice // J. Environ. Biol.-2010.-31, N 5.-P. 615-621.

18. Yang Z.-W., Ji B.-P., Zhou F., Li B., Luo Y., Yang L., Li T. Hypocholesterolaemic and antioxidant effects of kombucha tea in high-cholesterol fed mice // J. Sci. Food Agricult.-2009.-89, N 1.-P. $150-156$

19. Banerjee D., Hassarajani S. A., Maity B., Narayan G., Bandyopadhyay $S$. K., Chattopadhyay $S$. Comparative healing property of kombucha tea and black tea against indomethacin-induced gastric ulceration in mice: possible mechanism of action // Food Funct.-2010.-1, N 3.-P. 284-293.

20. Cavusoglu K., Guler P. Protective effect of kombucha mushroom $(\mathrm{KM})$ tea on chromosomal aberrations induced by gamma radiation in human peripheral lymphocytes in vitro // J. Environ. Biol.-2010.-31, N 5.-P. 851-856.
21. Bhattacharya S., Gachhui R., Sil P. C. Hepatoprotective properties of kombucha tea against TBHP-induced oxidative stress via suppression of mitochondria dependent apoptosis // Pathophysiology.-2011.-18, N 3.- P. 221-234.

22. Danielian L., Avagyan A. Influence of cultural liquid of Kombucha to immune system within the intestinal chicken infections // Biol. J. Armenia.-2001.-53.-P. 200-205.

23. Murugesan G. S., Sathishkumar M., Swaminathan K. Supplementation of waste tea fungal biomass as a dietary ingredient for broiler chicks // Bioresource Technol.-2005.-96, N 16.-P. 1743 1748.

24. Nguyen V. T., Gidley M. J., Dykes G. A. Potential of a nisin-containing bacterial cellulose film to inhibit Listeria monocytogenes on processed meats // Food Microbiol.-2008.-25, N 3.P. 471-478.

25. Yadav V., Panilaitis B., Shi H., Numuta K., Lee K., Kaplan D. L. $\mathrm{N}$-acetylglucosamine 6-phosphate deacetylase (nagA) is required for N-acetyl gucosamine assimilation in Gluconacetobacter xylinus // PLoS One.-2011.-6, N 6.-e18099.

26. Gill S. R., Pop M., Deboy R. T., Eckburg P. B., Turnbaugh P. J., Samuel B. S., Gordon J. I., Relman D. A., Fraser-Liggett C. M., Nelson K. E. Metagenomic analysis of the human distal gut microbiome // Science.-2006.-312, N 5778.-P. 1355-1359.

27. Backhed F., Ding H., Wang T., Hooper L. V., Koh G. Y., Nagy A., Semenkovich C. F., Gordon J. I. The gut microbiota as an environmental factor that regulates fat storage // Proc. Natl Acad. Sci. USA.-2004.-101, N 44.-P. 15718-15723.

28. Eckburg P. B., Bik E. M., Bernstein C. N., Purdom E., Dethlefsen L., Sargent M., Gill S. R., Nelson K. E., Relman D. A. Diversity of the human intestinal microbial flora // Science.-2005.308, N 5728.-P. 1635-1638.

29. Nam Y. D., Jung M. J., Roh S. W., Kim M. S., Bae J.W. Comparative analysis of Korean human gut microbiota by barcoded pyrosequencing // PLoS One.-2011.-6, N 7 e22109.

30. Lemaitre B., Nicolas E., Michaut L., Reichhart J. M., Hoffmann J. $A$. The dorsoventral regulatory gene cassette spatzle/Toll/cactus controls the potent antifungal response in Drosophila adults // Cell.-1996.-86, N 6.-P. 973-983.

31. Poltorak A., He X., Smirnova I., Liu M. Y., Van Huffel C., Du X., Birdwell D., Alejos E., Silva M., Galanos C., Freudenberg M., Ricciardi-Castagnoli P., Layton B., Beutler B. Defective LPS signaling in $\mathrm{C} 3 \mathrm{H} / \mathrm{HeJ}$ and $\mathrm{C} 57 \mathrm{BL} / 10 \mathrm{ScCr}$ mice: mutations in Tlr4 gene // Science.-1998.-282, N 5396.-P. 2085-2088.

32. Steinman R. M., Cohn Z. A. Identification of a novel cell type in peripheral lymphoid organs of mice I. Morphology, quantification, tissue distribution // J. Exp. Med.-1973.-137, N 5.-P. 1142 1162.

33. Bowie A. G., Unterholzner L. Viral evasion and subversion of pattern-recognition receptor signalling // Nat. Rev. Immunol.-2008.8, N 12.-P. 911-922.

34. Inohara N., Nunez G. NODs: intracellular proteins involved in inflammation and apoptosis // Nat. Rev. Immunol.-2003.-3, N 5.-P. 371-382.

35. Meylan E., Tschopp J., Karin M. Early epithelial responses to the microflora fall into the realm of the innate immune system, the first line of defense against intruders of the body // Nature.2006.-442, N 7098.-P. 39-44.

36. Takeda K., Kaisho T., Akira S. Toll-like receptors // Annu. Rev. Immunol.-2003.-21.-P. 335-376.

37. Yoneyama M., Fujita T. Function of RIG-I-like receptors in antiviral innate immunity // J. Biol. Chem.-2007.-282, N 21.P. 15315-15318.

38. Zhao Y., Yang J., Shi J., Gong Y. N., Lu Q., Xu H., Liu L., Shao F. The NLRC4 inflammasome receptors for bacterial flagellin and 
type III secretion apparatus // Nature.-2011.-477, N 7366.P. 596-600.

39. Aggarwal S., Ghilardi N., Xie M. H., de Sauvage F. J., Gurney A. $L$. Interleukin-23 promotes a distinct $\mathrm{CD} 4 \mathrm{~T}$ cell activation state characterized by the production of interleukin-17 // J. Biol. Chem.2003.-278, N 3.-P. 1910-1914.

40. Takahashi T., Kuniyasu Y., Toda M., Sakaguchi N., Itoh M., Iwata M., Shimizu J., Sakaguchi S. Immunologic self-tolerance maintained by $\mathrm{CD} 25^{+} \mathrm{CD} 4^{+}$naturally anergic and autoimmune disease by breaking their anergic/suppressive state // Int. Immunol.-1998.-10, N 12.-P. 1969-1980.

41. Livolsi A., Busuttil V., Imbert V., Abraham R. T., Peyron J. F. Tyrosine phosphorylation-dependent activation of NF- $\kappa B$ requirement for $\mathrm{p} 56 \mathrm{LCK}$ and ZAP-70 protein tyrosine kinases // Eur. J. Biochem.-2001.-268, N 5.-P. 1508-1515.

42. Perkins $N$. D. Integrating cell-signalling pathways with NF-kB and IKK function // Nat. Rev. Mol. Cell Biol.-2007.-8, N 1.P. 49-62.

43. Heuvelin E., Lebreton C., Grangette C., Pot B., Cerf-Bensussan $N$., Heyman M. Mechanisms involved in alleviation of intestinal inflammation by Bifidobacterium breve soluble factors // PLoS One.-2009.-4, N 4.--e5184.

44. Petrof E. O., Claud E. C., Sun J., Abramova T., Guo Y., Waypa T. S., He S. M., Nakagawa Y., Chang E. B. Bacteria-free solution derived from Lactobacillus plantarum inhibits multiple NF-kappaB pathways and inhibits proteasome function // Inflamm. Bowel Dis.-2009.-15, N 10.-P. 1537-1547.

45. Ben-Neriah Y., Schmidt-Supprian M. Epithelial NF-kappaB maintains host gut microflora homeostasis // Nat. Immunol.-2007.8, N 5.-P. 479-481.

46. Kelly D., Campbell J. I., King T. P., Grant G., Jansson E. A., Coutts A. G., Pettersson S., Conway S. Commensal anaerobic gut bacteria attenuate inflammation by regulating nuclear-cytoplasmic shutting of PPAR-gamma and ReIA // Nat. Immunol.-2004.5, N 1.-P. 104-112.

47. Hall J. A., Bouladoux N., Sun C. M., Wohlfert E. A., Blank R. B., Zhu Q., Grigg M. E., Berzofsky J. A., Belkaid Y. Commensal DNA limits regulatory $\mathrm{T}$ cell conversion and is a natural adjuvant of intestinal immune responses // Immunity.-2008.-29, N 4.-P. 637-649.

48. Atarashi K., Nishimura J., Shima T., Umesaki Y., Yamamoto M., Onoue M., Yagita H., Ishii N., Evans R., Honda K., Takeda K. ATP drives lamina propria $\mathrm{T}(\mathrm{H}) 17$ cell differentiation // Nature.-2008.-455, N 7214.-P. 808-812.

49. Lakhdari O., Tap J., Beguet-Crespel F., Le Roux K., de Wouters T., Cultrone A., Nepelska M., Lefevre F., Dore J., Blottiere H. M. Identification of NF- $\mathrm{KB}$ modulation capabilities within human intestinal commensal bacteria // J. Biomed. Biotechnol.-2011.2011.-P. 282356.

50. Lathrop S. K., Bloom S. M., Rao S. M., Nutsch K., Lio C. W., Santacruz N., Peterson D. A., Stappenbeck T. S., Hsieh C. S. Peripheral education of the immune system by colonic commensal microbiota // Nature.-2011.-478, N 7368.-P. 250-254.

51. Atarashi K., Tanoue T., Shima T., Imaoka A., Kuwahara T., Momose Y., Cheng G., Yamasaki S., Saito T., Ohba Y., Taniguchi T., Takeda K., Hori S., Ivanov I. I., Umesaki Y., Itoh K., Honda K. Induction of colonic regulatory $\mathrm{T}$ cells by indigenous Clostridium species // Science.-2011.-331, N 6015.-P. 337-341.

52. Gaboriau-Routhiau V., Rakotobe S., Lecuyer E., Mulder I., Lan A., Bridonneau C., Rochet V., Pisi A., De Paepe M., Brandi G., Eberl G., Snel J., Kelly D., Cerf-Bensussan N. The key role of segmented filamentous bacteria in the coordinated maturation of gut helper T cell responses // Immunity.-2009.-31, N 4.-P. 677-689.
53. Round J. L., Mazmanian S. K. Inducible Foxp $3^{+}$regulatory Tcell development by a commensal bacterium of the intestinal microbiota // Proc. Natl Acad. Sci. USA.-2010.-107, N 27.P. 12204-12209.

54. Allison K. R., Brynildsen M. P., Collins J. J. Metabolite-enabled eradication of bacterial persisters by aminoglycosides // Nature.2011.-473, N 7346.-P. 216-220.

55. Dicksved J., Floistrup H., Bergstrom A., Rosenquist M., Pershagen G., Scheynius A., Roos S., Alm J. S., Engstrand L., Braun-Fahrlander C., von Mutius E., Jansson J. K. Molecular fingerprinting of the fecal microbiota of children raised according to different lifestyles // Appl. Environ. Microbiol.-2007.-73, N 7.P. 2284-2289.

56. Mueller S., Saunier K., Hanisch C., Norin E., Alm L., Midtvedt T., Cresci A., Silvi S., Orpianesi C., Verdenelli M. C., Clavel T., Koebnick C., Zunft H. J., Dore J., Blaut M. Differences in fecal microbiota in different European study populations in relation to age, gender, and country: a cross-sectional study // Appl. Environ. Microbiol.-2006.-72, N 2.-P. 1027-1033.

57. Blaser M. J., Falkow $S$. What are the consequences of the disappearing human microbiota? // Nat. Rev. Microbiol.-2009.-7, N 12.- P. 887-894.

58. Turnbaugh P. J., Ley R. E., Mahowald M. A., Magrini V., Mardis E. R., Gordon J. I. An obesity-associated gut microbiome with increased capacity for energy harvest // Nature.-2006.-444, N 7122.-P. 1027-1031.

59. Cani P. D., Amar J., Iglesias M. A., Poggi M., Knauf C., Bastelica D., Neyrinck A. M., Fava F., Tuohy K. M., Chabo C., Waget A., Delmee E., Cousin B., Sulpice T., Chamontin B., Ferrieres J., Tanti J. F., Gibson G. R., Casteilla L., Delzenne N. M., Alessi M. C., Burcelin R. Metabolic endotoxemia initiates obesity and insulin resistance // Diabetes.-2007.-56, N 7.-P. 17611772.

60. Holmes E., Loo R. L., Stamler J., Bictash M., Yap I. K., Chan Q., Ebbels T., De Iorio M., Brown I. J., Veselkov K. A., Daviglus M. L., Kesteloot H., Ueshima H., Zhao L., Nicholson J. K., Elliott P. Human metabolic phenotype diversity and its association with diet and blood pressure // Nature.-2008.-453, N 7193.- P. 396400.

61. O'Keefe S. J. Nutrition and colonic health: The critical role of the microbiota // Curr. Opin. Gastroenterol.-2008.-24, N 1.-P. 51-58.

62. Lee Y. K., Menezes J. S., Umesaki Y., Mazmaniana S. K. Proinflammatory T-cell responses to gut microbiota promote experimental autoimmune encephalomyelitis // Proc. Natl Acad. Sci. USA.-2011.-108, Suppl. 1.-P. 4615-4622.

63. Drakes M., Blanchard T., Czinn S. Bacterial probiotic modulation of dendritic cells // Infect. Immun.-2004.-72, N 6.-P. 32993309.

64. Hegazy S. K., El-Bedewy M. M. Effect of probiotics on pro-inflammatory cytokines and NF-kappaB activation in ulcerative colitis // World J. Gastroenterol.-2010.-16, N 33.-P. 4145-4151.

65. Castillo N. A., Perdigon G., de Moreno de LeBlan A. Oral administration of a probiotic Lactobacillus modulates cytokine production and TLR expression improving the immune response against Salmonella enterica serovar Typhimurium infection in mice // BMC Microbiol.-2011.-11.-P. 177.

66. Schlee M., Harder J., Koten B., Stange E. F., Wehkamp J., Fellermann $K$. Probiotic lactobacilli and VSL\#3 induce enterocyte beta-defensin 2 // Clin. Exp. Immunol.-2008.-151, N 3.-P. 528535.

67. de LeBlanc Ade M., Castillo N. A., Perdigon G. Anti-infective mechanisms induced by a probiotic Lactobacillus strain against Salmonella enterica serovar Typhimurium infection // Int J. Food Microbiol.-2010.-138, N 3.-P. 223-231. 
68. Schiffrin E. J., Rochat F., Link-Amster H., Aeschlimann J. M., Donnet-Hughes A. Immunomodulation of human blood cells following the ingestion of lactic acid bacteria // J. Dairy Sci.1994.-78, N 3.-P. 491-497.

69. Ghadimi D., Folster-Holst R., de Vrese M., Winkler P., Heller $K$. J., Schrezenmeir J. Effects of probiotic bacteria and their genomic DNA on TH1/TH2-cytokine production by peripheral blood mononuclear cells (PBMCs) of healthy and allergic subjects // Immunobiology.-2008.-213, N 8.-P. 677-692.

70. Duary R. K., Bhausaheb M. A., Batish V. K., Grover S. Anti-inflammatory and immunomodulatory efficacy of indigenous probiotic Lactobacillus plantarum Lp91 in colitis mouse model // Mol. Biol. Rep.-2011.-DOI: 10.1007/s11033-011-1269-1.

71. Amdekar S., Singh V., Singh D. D. Probiotic therapy: immunomodulating approach toward urinary tract infection // Curr. Microbiol.-2011.-63, N 5.-P. 484-490.

72. Schwab M., Reynders V., Loitsch S., Steinhilber D., Schroder O. Stein $J$. The dietary histone deacetylase inhibitor sulforaphane induces human beta-defensin-2 in intestinal epithelial cells // Immunology.-2008.-125, N 2.-P. 241-251.

73. Corr S. C., Li Y., Riedel C. U., O'Toole P. W., Hill C., Gahan C. $G$. Bacteriocin production as a mechanism for the antiinfective activity of Lactobacillus salivarius UCC118 // Proc. Natl Acad. Sci. USA.-2007.-104, N 18.-P. 7617-7621.

74. Fukuda S., Toh H., Hase K., Oshima K., Nakanishi Y., Yoshimura Y., Tobe T., Clarke J. M., Topping D. L., Suzuki T., Taylor T.
D., Itoh K., Kikuchi J., Morita H., Hattori M., Ohno H. Bifidobacteria can protect from enteropathogenic infection through production of acetate // Nature.-2011.-469, N 7331.-P. 543-547.

75. Sonnenburg J. L., Chen C. T., Gordon J. I. Genomic and metabolic studies of the impact of probiotics on a model gut symbiont and host // PLoS Biol.-2006.-4, N 12.-e413.

76. Bravo J. A., Forsytheb P., Chewb M. V., Escaravageb E., Savignaca H. M., Dinana T. G., Bienenstockb J., Cryana J. F. Ingestion of Lactobacillus strain regulates emotional behavior and central GABA receptor expression in a mouse via the vagus nerve // Proc. Natl Acad. Sci. USA.-2011.-108, N 38.-P. 16050 16055.

77. Kozyrovska N., Foing B. H. Kombucha might be promising probiotics for consumption on the Moon // Abstract Book COSPAR 38 (Bremen, Germany, 2010).-Bremen, 2010.-P. 3.

78. Ovcharenko L. P., Kozyrovska N. O. Metagenomic analysis for microbial ecology and biotechnology // Biopolym. Cell.-2008.24, N 3.-P. 199-211.

79. Baugher J. L., Klaenhammer T. R. Invited review: Application of omics tools to understanding probiotic functionality // J. Dairy Sci.-2011.-94, N 10.-P. 4753-4765.

80. Dunham M. J. Synthetic ecology: A model system for cooperation// Proc. Natl Acad. Sci. USA.-2007.-104, N 6.-P. 1741-1742.

Received 25.01.12 